\title{
Karakteristik Makro Algae Berzat Kapur di Perairan Tanjung Sira Lombok-Barat
}

\author{
Achmad Kadi \\ Pusat Penelitian Oseanografi - LIPI \\ Jl. Pasir Putih I no. 1 Ancol - Timur, Jakarta - Utara
}

\begin{abstract}
Coastal waters of Tanjung Sira has calcareousalgae of the genus Halimeda limestone, Padina, Amphiroa, Galaxaura, Corallina, Hydrolithon, Mesophyllum, Peysonallia, Porolithon and Sporolithon. The substrate that used as habitat are sand, coarse sand, rocks and dead coral rubble. Calcium carbonate contained on calcareous algae fungsioning as adhesive and encrusting dead coral, shells of mollusks that have decayed and massive objects in the waters of the sea. The research aims was to determine the growth characteristics of calcareousalgae in the reef flats, local distribution, calcium carbonate contain and its contribution as a frame work coastal reef waters. The research method using transect (Buckland et al., 1993). Identification of the type of aragonite and calcite according to Cordero (1977). Analysis of calcium carbonate according to Hillis (1980). The results showed that the green and brown calcareousalgae found in the reef flats, has thallus and tubers. Red calcareousalgae grew as encrusting on dead reefs and massif substrate. There are 16 species of calcareous algae that found in reseach area, 10 species containing aragonite mineral and 6 species containing calcite mineral. The content of calcium carbonate on each species obtained $100-450 \mathrm{~g} / \mathrm{m}^{2}$ consists of aragonite and calcite minerals. Calcareousalgae contribute in the new formation of coral reef ecosystems. The other benefit of calcareaousalgae in the coastal waters is an additional food for herbivorous fish. The content of calcium carbonate on calcareousalgae species is used in pharmaceutical field as drug ingredients and supplements for humans.
\end{abstract}

Keywords: calcareousalgae, Tanjung Sira, coastal waters, west Lombok

\begin{abstract}
Abstrak
Perairan Pantai Tanjung Sira memiliki makro algae berzat kapur dari marga Halimeda, Padina, Amphiroa, Galaxaura, Corallina, Hydrolithon, Mesophyllum Peysonallia, Porolithon dan Sporolithon. Habitat di subtrat pasir, pasir kasar, batu karang dan pecahan karang mati. Kandungan kalsium karbonat merupakan penyelimut atau perekat karang mati, cangkang moluska yang telah lapuk dan benda-benda bersifat massive yang berada di perairan laut. Penelitian makro algae berzat kapur ini bertujuan untuk mengetahui karakteristik pertumbuhan dibeberapa mintakat habitat paparan terumbu, sebaran lokal, kandungan kalsium karbonat dan sumbangannya di perairan pantai. Metode penelitian menggunakan survai dan transek garis dalam kuadrat (Buckland et al., 1993.) Identifikasi tipe aragonit dan kalsit menurut Cordero (1977). Analisa kandungan kalsium karbonat menurut Hillis (1980). Hasil penelitian menunjukan bahwa makro algae berzat kapur kelas hijau dan coklat berthallus dan berubi, kebanyakan tumbuh bersifat menancap atau menempel pada substrat, berada di paparan intertidal dan subtidal seperti marga Halimeda dan Padina. Makro algae berzat kapur dari Kelas merah tumbuh bersifat menyelimuti atau perekat substrat yang berada di paparan subtidal, punggung terumbu dan tubir seperti marga Corallina dan Peysonallia. Jenis seluruhnya ada 16 jenis yakni 10 jenis mengandung mineral aragonit dan 6 jenis mengandung mineral kalsit. Kandungan kalsium karbonat terendah dan tertinggi di peroleh $100-450 \mathrm{~g} / \mathrm{m}^{2}$ dari meneral aragonit dan kalsit. Makro algae berzat kapur ikut andil dalam pembentukan ekosistem terumbu karang baru dan sebagai sediaan pakan tambahan bagi ikan herbivora. Kandungan kalsium karbonat dibidang farmasi bermanfaat bagi manusia sebagai bahan obat dan supplemen.
\end{abstract}

Kata Kunci: Makro alga berzat kapur, Perairan Tanjung Sira, Lombok-Barat

\section{Pendahuluan}

Makro algae berzat kapur atau disebut juga Calcariousalgae tumbuh di habitat paparan terumbu karang pada substrat batu karang, pecahan karang mati, pasir kasar dan pasir. Makro algae terdiri atas kelompok bertulang (articulate) dan kerak (crustose) dapat membentukan karbonat masa kini (Carbonat recent). Kandungan kalsium karbonat $\left(\mathrm{CaCO}_{3}\right)$ sebagai hasil metabolisme berupa mineral aragonit dan kalsit. Sebarannya dapat dijumpai di 
perairan laut tropik dan subtropik, sampai pada kedalaman 1-300 m (Cordero, 1977). Di Indonesia berjumlah mencapai 103 jenis (Bosse, 1928). Marga yang mudah diperoleh di perairan pantai Indonesia adalah Halimeda, Padina, Amphiroa, Galaxaura, Corallina, Hydrolithon, Mesophyllum, Peysonallia, Porolithon dan Sporolithon.

Makro algae berzat kapur dalam ekosistem pantai mempunyai arti yang sangat penting pada pembentukan ekosistem terumbu karang baru yakni ikut membentuk endapan kalsium karbonat baru yang bersifat porius sangat dibutuhkan dalam sistem phycocolloid reef merupakan persedian hydrocarbon masa kini. Wray (1977) menambahkan bahwa makro algae berzat kapur di daerah paparan terumbu karang sebagai persediaan pakan additive bagi ikan-ikan herbivora melalui grazing dan browzing dalam memenuhi kebutuhan $\mathrm{CaCO}_{3}$ untuk pertumbuhan tulang.

Cordero (1977) menyatakan bahwa kelompok jenis makro algae berzat kapur mempunyai sifat fisik yang berbeda-beda dengan penggolongan jenis berdasarkan pada kandungan kalsium karbonat yang ada didalam sel thallus yakni; kandungan kalsium karbonat tipe aragonit berada di permukaan dinding sel dan tipe kalsit berada di dalam dinding sel. Pengelom-pokan sifat fisik calcarious algae antara lain calcarious algae articulate $\mathrm{CaCO}_{3}$ dibentuk mirip tulang bersusun skeleton seperti marga corallina sedangkan calcarious algae crustose $\mathrm{CaCO}_{3}$ dibentuk seperti berkerak (Encrusting algae) thallus tipis menempel di batuan (Epilitik algae), lembaran dan segmen-segmen (Dawson, 1966).

Tujuan penelitian untuk mengetahui makro algae berzat kapur mengenai karakteristik pertumbuhannya dibeberapa bagian habitat paparan terumbu, sebaran lokal, kandungan $\mathrm{CaCO}_{3}$ dan sumbangannya di pantai paparan terumbu karang
Tanjung Sira Lombok-Barat, yang terletak pada koordinat $115^{\circ}-115^{\circ} 30^{\prime} 00^{\prime \prime}$ B.T. dan $07^{\circ} 30^{\prime}-08^{\circ} 30^{\prime} 0^{\prime \prime}$ LS (Gambar 1). Sampel makro algae berzat kapur diambil pada Bulan Mei tahun 2012 dengan metode survai menggunakan transek garis dalam kuadrat $1 \times 1 \mathrm{~m}^{2}$ setiap $10 \mathrm{~m}$ ke arah tubir dan ditambah koleksi bebas (Buckland et al., 1993). Identifikasi jenis makro algae kandungan $\mathrm{CaCO}_{3}$ tipe aragonit dan kalsit dengan kunci list of calcarious algae (Cordero,1977) dan (Connel, 1974).

Kandungan $\mathrm{CaCO}_{3}$ diperoleh dari masing-masing marga menggunakan larutan $\mathrm{HCl}$ pekat, dilakukan penimbangan untuk mengetahui berat kering kandungan zat kapur tiap-tiap marga dalam $\left(1 \times 1 \mathrm{~m}^{2}\right)$. Sampel dikeringkan dalam oven $60^{\circ} \mathrm{C}$ sampai kering, kemudian ditimbang dan dilarutkan pada $\mathrm{HCl}$ pekat.

\section{Materi dan Metode}

Penelitian Makro alagae berzat kapur ini dilaksanakan di Paparan Tanjung Sira Pulau Lombok bagian barat Nusa TenggaraBarat. Penelitian ini terdiri atas dua tahap yaitu penelitian lapangan dan laboratorium. Penelitian lapangan sampel makro algae berzat kapur diambil dengan metode survai menggunakan transek garis dalam kuadrat $1 \times 1 \mathrm{~m}^{2}$ setiap $10 \mathrm{~m}$ ke arah tubir (Buckland et al., 1993). Penelitian laboratorium untuk identifikasi jenis makro algae berzat kapur tipe aragonit dan kalsit menurut Cordero (1977) dan kandungan kalsium karbonat di analisa berdasarkan Hillis (1980) dengan menggunakan $\mathrm{HCl}$ pekat, sehingga zat kapur akan terlepas dari thallus yang tertinggal serat-serat thallus beserta segmennya, thallus dikeringkan selanjutnya ditimbang kembali. Selisih berat kering thallus awal dikurangi berat serat thallus kering akhir adalah berat kandungan zat kapur dari masing-masing jenis $\left(\mathrm{g} / \mathrm{m}^{2}\right)$. 


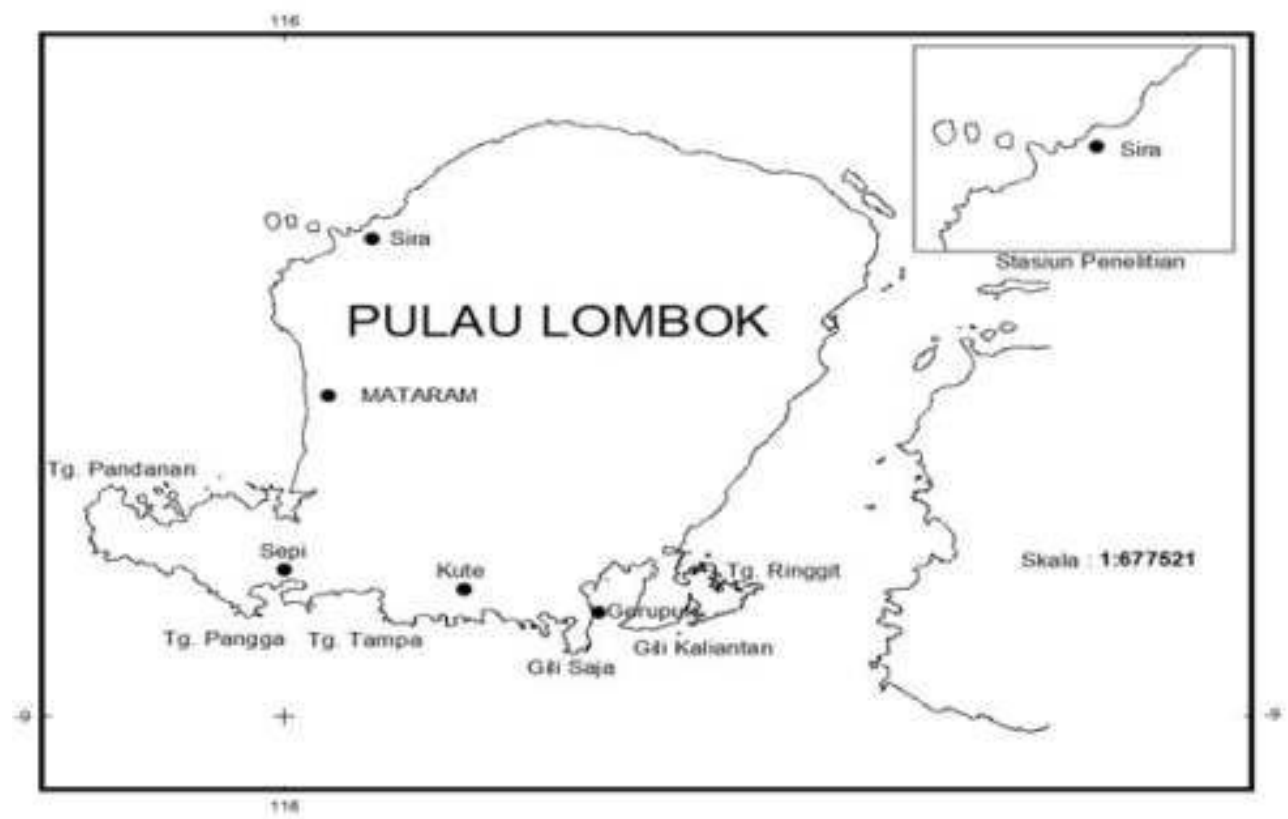

Gambar 1. Peta Perairan Pantai Tanjung Sira, Lombok-Barat.

\section{Hasil dan Pembahasan}

\section{Habitat dan sebaran lokal di Terumbu karang}

Habitat makro algae berzat kapur atau lingkungan tempat tumbuh di Pantai Tanjung Sira berpaparan terumbu terbagi dalam beberapa paparan sampai ke arah tubir, dengan kedalaman 0,5-10 m. Makro algae ini kebanyakan tumbuh pada suhu $\pm 20-30^{\circ}$ C, kadar garam 30-39\% dan $\mathrm{pH}$ air 7-8,5. Pada lingkungan ekstrim dapat tumbuh di kedalaman sampai mencapai $200 \mathrm{~m}$ atau lebih (Dawson,1966).

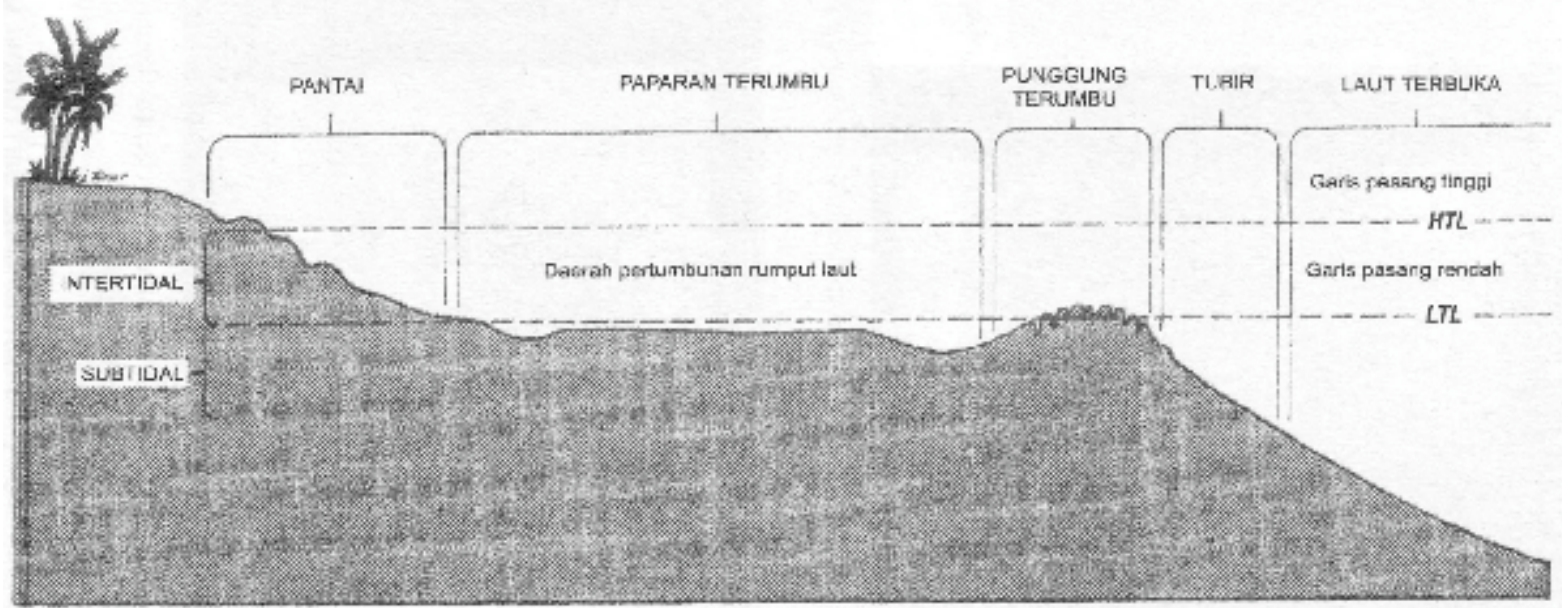

Gambar 2. Mintakat paparan terumbu di Pantai Tanjung Sira Lombok-Barat.

\section{Area Intertidal (Beach)}

Area intertidal merupakan bagian dari di paparan terumbu pantai yang dangkal Beach-zone (Gambar 2). Area intertidal ini biasanya sebagai habitat makro algae berzat kapur tumbuh pada substrat pasir dan pecahan karang mati, pada waktu surut terendah masih ada sisa air. Area intertidal banyak dijumpai pertumbuhan dari marga Halimeda., Amphiro, galaxaura dan algae kerak. (Matsuura et al., 2006). Karakteristik kalsifikasi terjadi pada semua bagian thallus di dinding maupun di dalam jaringan sel. Kandungan kalsium karbonat pada thallus yang telah tua lunak dan rapuh berada di 
paparan terumbu membentuk suatu endapan yang bersifat porius sebagai sistem phycocolloid reef. Round (1980) menambahkan bahwa persedian endapan kalsium karbonat ini merupakan bahan pakan tambahan bagi ikan herbivora dan biota lain.. Sebaran di perairan Tanjung Sira ada 10 jenis terdiri dari Halimeda macroloba, $H$. Macrophysa, H. Opuntia, H. Tuna, H. Cylindracea, H. Cuneata, H. Discoidea, Padina australis, Amphiroa crassa dan Galaxaura rugosa (Tabel 1). Kelas Rhodophyceae di Tanjung sira ada 8 jenis keberadaannya lebih banyak dari pada yang berada Pantai Espirito Santo-Brazil ada 5 jenis (Ramos et al., 2010). Makro algae berzat kapur mempunyai thallus ada yang menempel atau menancap pada substrat pasir, dengan holfast berubi (bulbous). Jenis Halimeda macroloba dan $H$. Cylindraceae, ada keunikan tersendiri yakni holfas berubi dapat mengikat partikel-partikek pasir yang lebih besar, sehingga dalam komunitas yang besar mampu menahan kikisan erosi pasir dari hempasan ombak dan apabila terjadi gempuran ombak. Pada waktu kekeringan yang berlebihan thallus kandungan $\mathrm{CaCO}_{3}$ berupa aragonit dan kalsit akan berwarna putih dan akan berlanjut pada kematian.

\section{Area Subtidal (Reef Flats)}

Area substidal merupakan bagian dari paparan terumbu, dimana pada waktu air surut rendah sebagian besar substrat tidak pernah mengalami kekeringan, batas area ini sampai pada daerah punggung terumbu (Gambar 2). Habitat bersubstrat batu karang, pecahan karang dan karang mati. Paparan turumbu kadang-kadang berkubangan sebagai tempat ideal bagi pertumbuhan makro algae, apabila thallus skeleton dan kerak dalam keadaan air kering akan mudah mati. Sebaran algae berzat kapur di perairan Tanjung Sira ada 16 jenis kebanyakan dari kelas Chlorophyceae marga Halimeda, Phaeophyceae marga Padina dan Rhodophyceae marga Amphiroa, Corallina, Galaxaura, Hydrolithon, Mesophyllum, Peyssonellia, Porolithon dan Sporolithon (Tabel 1). Makro algae berzat kapur dapat dijumpai di area subtidal di perairan Philiphine ada 16 jenis dan beberapa jenis mempunyai kesamaan (Cordero, 1977). Karakteristik makro algae ini berthallus rapuh dan keras, kandungan kalsium karbonat yang di bentuk dari tipe kalsit dan aragonit cukup tinggi, merupakan hasil penumpukan metabolisme berupa $\mathrm{CaCO}_{3}$ berfungsi sebagai perekat kerangka karang mati, cangkang-cangkang moluska dan benda-benda keras yang ada didasar perairan, sehingga kerangka karang yang mati tetap tegak dan dapat menahan gempuran ombak besar (Wilson et al., 2004). Semen perekat yang sangat kuat ini banyak dihasilkan dari metabolisme marga Peyssonellia dan Corallina

\section{Area Punggung Terumbu (Ridge)}

Punggung terumbu adalah area batas bagian dalam dengan ujung paparan terumbu, letaknya membujur searah garis pantai berbentuk pematang bergunduk atau bongkahan bertanggul ada yang tinggi dan rendah (Gambar 2). Substrat punggung terumbu terbentuk dari bongkahan karang bolder atau karang massive. Area ini merupakan habitat utama bagi semua jenis makro algae berzat kapur, dibagian substrat dinding punggung yang mencuat keatas kebanyakan diselimuti oleh makro algae kerak. Sebaran makro algae berzat kapur di perairan Tanjung Sira ada 15 jenis di jumpai pada bagian bongkahan yang selalu tergenang air. Keberadaan marga Halimeda, Porolithon, Sporolithon dan algae kerak berguna sebagai perekat untuk karang mati yang berada di punggung terumbu (Tabel 1). Makro algae berzat yang berada di punggung terumbu berfungsi sebagai perekat bongkahan karang yang mati, dalam ekosistem terumbu karang sebagai penahan ombak besar paling utama, sebelum ombak sampai di tepi pantai akan pecah dan terurai.

\section{Area Tubir (Reef Slope)}

Area tubir adalah merupakan dinding luar punggung terumbu (Gambar 2), sebagai habitat utama karang hidup dan makro algae berzat kapur. Sebaran di pantai Tanjung Sira dijumpai ada 11 jenis terdiri dari kelas Chlorophyceae marga Halimeda, kelas Phaeophyeae marga Padina dan kelas Rhodophyceae marga Corallina, Hydrolithon, Mesophyllum, Peysonellia, Porolithon dan sporolithon (Tabel 1). Area tubir bagi makro algae berzat kapur dapat tumbuh menyelimuti dan mengikat bonggol karang yang lapuk dengan semen kalsium karbonat seperti karang marga Acropora, sehingga percabangan karang bertambah 
kokoh. Penyelimutan ini terjadi pada marga Peysonallia yang merupakan hasil metabolisme yang berwarna merah marun, merah tua dan ungu. Penyelimutan ini dapat di lihat di daerah karang-karang mati yang telah lapuk, keberadaannya sampai pada kedalaman 5-40 meter (Kongwe, 2006).

\section{Kandungan Kalsium Karbonat alam di Terumbu Karang}

\section{Kalsium Karbonat}

Kandungan makro algae berzat kapur sebagai penghasil kalsium karbonat (Gambar 4-7). Kalsium karbonat diperoleh melalui hasil metabolisme yang disimpan atau diendapkan di dalam jaringan sel thallus, termasuk dalam kelompok articulate bertulang, sedangkan kelompok crustose berkerak disimpan di permukaan sel. Makro algae berzat kapur di Pantai Tanjung Sira mempunyai dua tipe aragonat kalsium karbonat termasuk calcarious algae hijau, coklat dan sebagian merah. Kandung-an aragonit, dapat membentuk crustose berkerak atau endapan hydrocarbon sebagai kalsium karbonat yang bersifat porius, tumbuh menempel dibatuan (algae epilitik) atau menancap pada pasir. Kelompok lain adalah calcarious algae merah dengan kandungan kalsit akan membentuk sedimen articulate akan menghasilkan thallus bertulang skeleton sebagai endapan kalsium karbonat, tumbuh menempel atau menyelimuti benda lain. Produksi alami kalsium karbonat di paparan terumbu karang perairan Tanjung Sira ratarata mencapai 100-450 g/ $/ \mathrm{m}^{2}$ (Tabel 2). Namun masih lebih rendah dari pada yang terdapat di paparan terumbu Kepulauan One Tree Great Barrier Reef Australia mencapai $148-500 \mathrm{~g} / \mathrm{m}^{2}$. Kandungan kalsium karbonat ini menunjukan bahwa di perairan Tanjung Sira biomassa $\mathrm{CaCO}_{3}$ yang ada, tidak jauh berbeda dengan daerah lainnya. Klumpp dan McKinnon (1992) menambahkan bahwa kandungan kalsium karbonat ini tergantung pada kedalaman tempat tumbuh dan Sinar Matahari yang diterima dimasing-masing perairan akan berbeda. Odum dan Odum (1955) menyatakan bahwa penyerapan kalsium karbonat makro algae berzat kapur mencapai 7-38 \% adalah $\mathrm{CaCO}_{3}$ dengan kandungan mineral aragonit dan kalsit, sedangkan senyawa lain seperti karbonat magnesium dan karbonat stonium dalam jumlah yang sangat kecil sekali.

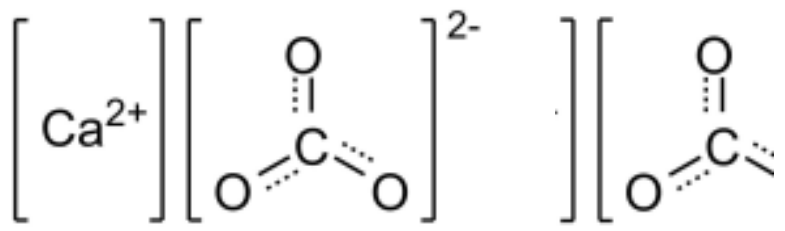

Gambar 3. Struktur kimia kalsium karbonat

Tabel 1. Makro algae berzat kapur Paparan Terumbu Karang Tanjung Sira Perairan Lombok.

\begin{tabular}{|c|c|c|c|c|}
\hline $\begin{array}{c}\text { Nama Makro Algae } \\
\text { Berzat Kapur }\end{array}$ & $\begin{array}{c}\text { Intertidal } \\
\text { (Beach) }\end{array}$ & $\begin{array}{c}\text { Subtidal } \\
\text { (Reef flats) }\end{array}$ & $\begin{array}{c}\text { Punggung } \\
\text { Terumbu (Ridge) }\end{array}$ & $\begin{array}{c}\text { Tubir } \\
\text { (Reef slope) }\end{array}$ \\
\hline \multicolumn{5}{|l|}{ Chlorophyta } \\
\hline Halimeda cuneata & + & + & + & + \\
\hline H. cylindracae & ++ & ++ & - & - \\
\hline H. discoidea & + & ++ & ++ & + \\
\hline H. macrophysa & + & + & ++ & + \\
\hline H. macroloba & ++ & ++ & - & - \\
\hline H. opuntia & ++ & ++ & ++ & ++ \\
\hline H. tuna & + & + & ++ & - \\
\hline \multicolumn{5}{|l|}{ Phaeophyta } \\
\hline Padina australis & + & ++ & + & + \\
\hline
\end{tabular}




\begin{tabular}{|c|c|c|c|c|}
\hline $\begin{array}{c}\text { Nama Makro Algae } \\
\text { Berzat Kapur }\end{array}$ & $\begin{array}{c}\text { Intertidal } \\
\text { (Beach) }\end{array}$ & $\begin{array}{c}\text { Subtidal } \\
\text { (Reef flats) }\end{array}$ & $\begin{array}{c}\text { Punggung } \\
\text { Terumbu (Ridge) }\end{array}$ & $\begin{array}{c}\text { Tubir } \\
\text { (Reef slope) }\end{array}$ \\
\hline \multicolumn{5}{|l|}{ Rhodophyta } \\
\hline Amphiroa canaliculata & - & ++ & + & - \\
\hline Galaxaura rugosa & - & + & + & - \\
\hline Corallina sp & - & ++ & + & + \\
\hline Hydrolithon reinboldii & - & + & ++ & + \\
\hline Mesophyllum mesomorphum & - & + & ++ & + \\
\hline Peysonallia rubra & - & + & ++ & ++ \\
\hline Porolithon gardineri & - & + & ++ & + \\
\hline Sporolithon erythraeum & - & + & + & + \\
\hline
\end{tabular}

Keterangan: + = sedikit ; ++ = banyak ; - = tidak ada

Kandungan $\mathrm{CaCO}_{3}$ apabila dipanaskan menjadi serbuk remah dan lunak yang dinamakan kalsium oksida $(\mathrm{CaO})$ reaksi tersebut setiap molekul dari kalsium akan bergabung dengan 1 atom oksigen dan molekul lainnya akan berikatan dengan oksigen menghasilkan $\mathrm{CO}_{2}$ akan melepas ke udara sebagai gas karbon dioksida, reaksi berlangsung sebagai berikut $\mathrm{CaCO}_{3} \mathrm{CaO}$ $+\mathrm{CO}_{2}$ (Gambar 3). Molekul dari $\mathrm{CaCO}_{3}$ akan segera mengikat molekul air $\left(\mathrm{H}_{2} \mathrm{O}\right)$ akan membentuk kalsium hidroksida zat yang lunak seperti pasta, dalam keadaan kering mengeras menjadi batuan kapur sebagai berikut. $\mathrm{CaCO}_{3}+\mathrm{H}_{2} \mathrm{O} \mathrm{Ca}(\mathrm{OH})_{2}+\mathrm{CO}_{2}$. Braga dan Riding (2005) manyatakan bahwa pasta hasil metabolisme calcarious algae kandungan aragonit dan kalsit, mampu sebagai perekat karang mati dan benda lain yang ada di dasar perairan, apabila dalam keadaan kering membentuk batuan kapur yang keras.

\section{Mineral Aragonit}

Kelas Chlorophyceae marga Halimeda, Phaeophyceae marga Padina dan Rhodophyceae marga Amphiroa dan Galaxaura mengandung kalsium karbonat, biasanya dari beberapa jenis makro algae

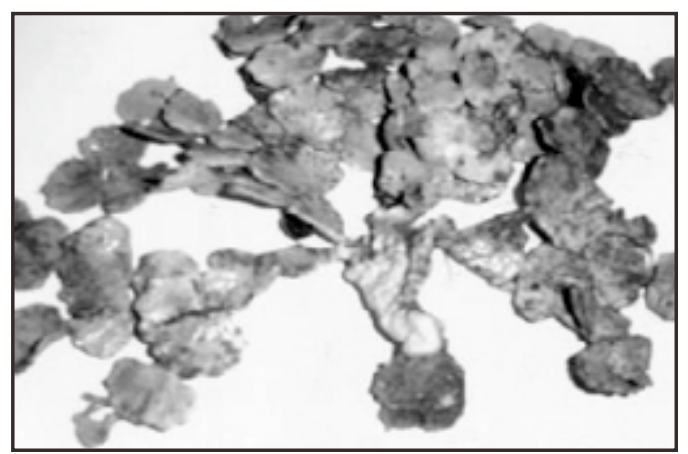

Gambar 4. Halimeda macroloba berzat kapur yang menempel pada kerangkerangan, kandungan aragonit lebih lunak (Tabel 2) dan (Gambar 4 dan 5). Tipe aragonit adalah mineral dari kalsium karbonat yang terbentuk pada suhu rendah, dalam bentuk polymorphous yakni rumus kimia yang sama tetapi struktur kristal yang berbeda dengan kalsit (Erich dan Pierre, 1999). Endapan kandungan aragonit lebih lunak, akan berubah menjadi kalsit pada suhu $380-470^{\circ} \mathrm{C}$.

\section{Mineral Kalsit}

Kelas Rhodophyceae marga Corallina, Hydrolithon, Mesophyllum, Peysonallia, Porolithon dan Sporolithon mengandung kalsium karbonat, kebanyakan algae merah ini mengandung mineral kalsit (Tabel 2) dan (Gambar 6 dan 7). Tipe kalsit adalah mineral pembentuk batuan dari kalsium karbonat sebagai polymorphous karbonat kasium yang paling stabil dengan struktur kristal keras (Erich dan Pierre, 1999). Polymorphous lain adalah mineral aragonit yang lebih lunak. Batuan kalsit ini sangat umum sebagian kerak bumi mineral dan banyak digunakan sebagai bahan kontruksi, perlakuan tanah pertanian, pigmen dan farmasi.

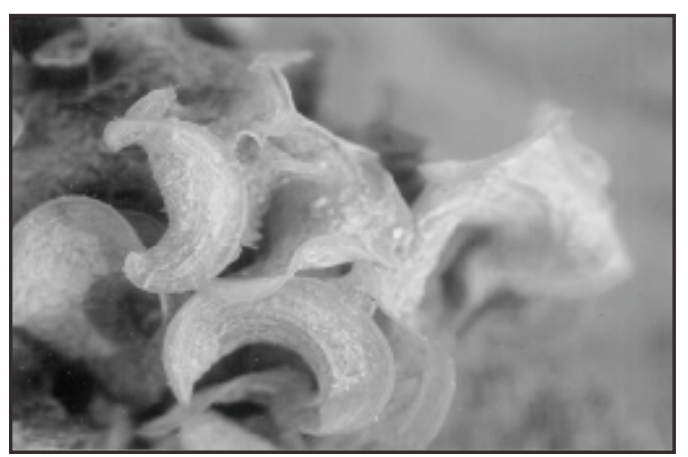

Gambar 5. Padina australis 


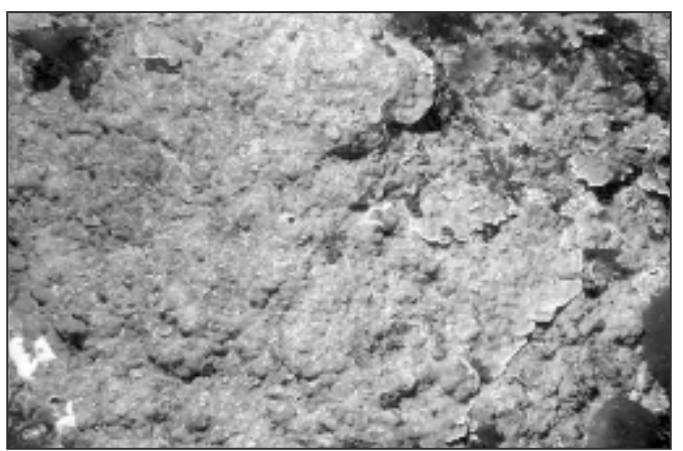

Gambar 6. Corallina sp. (Encrusting)

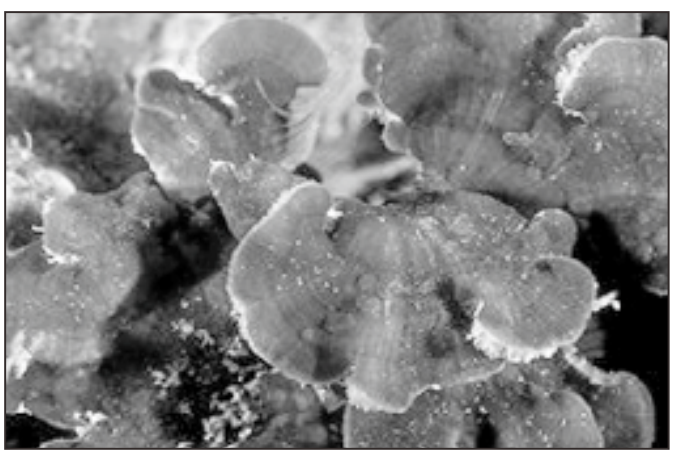

Gambar 7. Peysonallia rubra

Tabel 2. Beberapa kandungan kalsium karbonat makro algae berzat kapur $\left(\mathrm{g} / \mathrm{m}^{2}\right)$ di Paparan Terumbu Tanjung Sira Lombok Barat

\begin{tabular}{|c|c|c|c|c|}
\hline Kelas & Marga & $\begin{array}{l}\text { Tipe } \\
\text { Kalsium } \\
\text { Karbonat }\end{array}$ & $\begin{array}{l}\text { Bagian Tempat } \\
\text { penyimpanan }\end{array}$ & $\begin{array}{l}\text { Kalsium } \\
\text { Karbonat }\left(g / m^{2}\right)\end{array}$ \\
\hline Chlorophyceae & Halimeda & Aragonit & Permukaan sel & 125 \\
\hline Phaeophyceae & Padina & Aragonit & Permukaan sel & 100 \\
\hline \multirow{8}{*}{ Rhodophyceae } & Amphiroa & Aragonit & Permukaan sel & 200 \\
\hline & Galaxaura & Aragonit & Permukaan sel & 250 \\
\hline & Corallina & Kalsit & Dalam dinding sel & 450 \\
\hline & Hydrolithon & Kalsit & Dalam dinding sel & 300 \\
\hline & Mesophyllum & Kalsit & Dalam dinding sel & 400 \\
\hline & Peysonallia & Kalsit & Dalam dinding sel & 250 \\
\hline & Porolithon & Kalsit & Dalam dinding sel & 400 \\
\hline & Sporolithon & Kalsit & Dalam dinding sel & 400 \\
\hline
\end{tabular}

\section{Sumbangannya Makro Algae Berzat $\operatorname{Kapur}\left(\mathrm{CaCO}_{3}\right)$}

Makro algae berzat kapur di daerah Pantai sangat dibutuhkan turutama dalam pembentukan ekosistem terumbu karang baru, yakni kemampuan hasil penumpukan metabolisme $\mathrm{CaCO}_{3}$ dapat berfungsi sebagai perekat atau menyelimuti semua kerangka karang mati, cangkang kerang dan benda-benda keras yang ada didasar perairan, sehingga tidak mengalami kehancuran. Kandungan aragonit dan kalsit berada pada bagian permukaan dan di dalam dinding sel thallus sebagai endapan atau kerak $\mathrm{CaCO}_{3}$, mempunyai resistensi untuk menahan kikisan arus air dan gempuran ombak besar.

Peran algae berzat kapur dalam ekosistem terumbu karang sebagai tempat kamuplase bagi asuhan benih-benih ikan, moluska, krustacae dan biota lain agar terhindar dari kejaran predatornya. Kalsium carbonat dibutuhkan sebagai pakan additive dalam pembentukan tulang ikan herbivora, moluska, udang-udangan dan biota lain. Kandungan kalsium karbonat secara luas digunakan sebagai campuran makanan sebagai zat supplemen dan dalam industri sebagai campuran susu bubuk..Defisiensi kalsium karbonat dapat menimbulkan beberapa penyakit lordosis dan osteoporosis.

\section{Kesimpulan}

Makro algae berzat kapur di perairan Tanjung Sira ada 16 jenis, kandungan aragonit 10 jenis dan kalsit 6 jenis. Kandungan kalsium karbonat $\left(\mathrm{CaCO}_{3}\right)$ dari beberapa jenis mencapai $100-450 \mathrm{~g} / \mathrm{m}^{2}$ dalam bentuk aragonit dan kalsit yang berfungsi sebagai penyelimut dan perekat karang mati, cangkang muluska dan bendabenda keras di dasar perairan laut, sehingga paparan terumbu karang resisten terhadap arus deras dan gempuran ombak besar. Makro algae berzat kapur ikut andil bagi pembentukan ekosistem terumbu karang baru, Makro algae berzat kapur 
dibutuhkan sebagai pakan tambahan untuk ikan herbivora. Tempat asuhan bagi bibit ikan, udang, moluska dan biota lain. Kandungan $\mathrm{CaCO}_{3}$ dibutuhkan sebagai bahan additive bagi ikan herbivora dan manusia.

\section{Daftar Pustaka}

Buckland, S.T., D.R. Anderson, K.P. Burham, and J.L. Laake 1993. Distance sampling estimating abundance of biological population. First ed. Chapman and Hall Ltd., London. 3570 pp.

Bosse, A.W.V. 1928. Liste des algues du Siboga Rhodophyceae traisimi partieGigartinales et Rhodymeniales. Siboga Expeditie LIXd: 200-533.

Braga, J. C. and Riding 2005. Calcarious algae. In: Selley, R., Cooks, L R. M. and Plimer, I. J. R. (eds) Encyclopedia of Geology. Amsterdam; Elsevier, 428436.

Connel, Y. H. 1974. Seaweeds in the coral reef communities. In: Richard, N. and Mariscal (eds.). Field experiment in marine ecology. Academy Press, New york. 67-78.

Cordero, J. R. A. 1977. Studies on Philiphine marine red algae, Smithsonian Institution United State National Museum. Series IV: 258 pp.

Dawson, E.Y. 1966. Marine botany. An Introduction Smithsonian Institution United States National Museum. Holt, Rinehart and winston, Inc., New York. $284 \mathrm{pp}$.

Erich, S. K. and G. Pierre 1999. Microenviromental control on biomineralization: superficial processes of apatite and calcite precipitation in Quaternary soil Roussillon, France. Sedimentology. 46(3). 463-476.
Hillis-Colinvaux, L. 1980. Ecology and taxonomy of Halimeda; Primary producer of coral reefs. In: Blaxter, Russel and Yonge (eds.) Marine Biology. Academic Press, London. XVII: 2-84.

Klumpp, D.W. and A. D. Mckinnon 1992. Cummunity structure, biomss and productivity of epilithic algal communities on the Graet Barrier Reef: dynamics at different spatial scales. Mar. Ecol. Prog. Ser.Vol.86: 77-89.

Kongwe, J. 2006. Calcarious Algae of A Troical Lagoon; Primary Productivity, Calcification and Carbonat Production. Departement of Botany, Stockholm University, Sweden. 48 pp.

Matsuura, K., O. Sumadhiharga and K. Tsukamoto 2006. Field Guide to Lombok Island. 393-449.

Odum, H.T., and E.P.Odum 1955.Trophic strukture and productivity of windward coral reef community on Eniwetoll Atoll. Ecol. Monogr.25:281-320.

Ramos, R. J., M. P. Travassos and G. R. Leite 2010. Charakterization Macrofauna Associated with Articulated Calcarious algae (Corallinaceae, Rhodophyta) Occurring In A Hydrodynamic Gradient on The Espirito Santo State Coast, Brasilian Journal Of Oceanography, 58(4)275-285.

Round, F.E. 1980. The ecology of algae. Cambridge University Press., London. 325pp.

Wilson, S., C. Blake, J.A. Berges and C. A. Maggs 2004. Nothern Ireland. Elsevier, Bio. Cons. 120: 283-293.

Wray, J. I. 1977. Calcarious algae. Developments in Palaentology and Stratigraphy. Amsterdam: Elsevier, Vol. 4, $185 \mathrm{pp}$. 